agriTECH, 40 (1) 2020, 74-83

\title{
Sifat Fisik, Amilograf, dan Morfologi Pati Biji Lai (Durio kutejensis) Asetilasi Menggunakan Asetat Anhidrat
}

\author{
Physical, Amilograph and Morphological Properties of Lai Seed (Durio Kutejensis) \\ Starch Assylation using Acetate Anhydrat \\ Siti Masithah Fiqtinovri ${ }^{1 *}$, Ashri Mukhti Benita ${ }^{2}$, Djagal Wiseso Marseno ${ }^{3}$, Yudi Pranoto ${ }^{3}$ \\ ${ }^{1}$ Program Studi Agroteknologi, Fakultas Pertanian, Universitas Kaltara, \\ Jl. Sengkawit, Tanjung Selor, Kalimantan Utara 77212, Indonesia \\ ${ }^{2}$ Teknologi pangan, Fakultas Sains dan Teknologi, Universitas Nahdlatul Ulama Purwokerto, \\ Jl. Sultan Agung 42, Purwokerto Selatan 53144, Indonesia \\ ${ }^{3}$ Departemen Teknologi Pangan dan Hasil Pertanian, Fakultas Teknologi Pertanian, \\ Universitas Gadjah Mada, Jl. Flora No. 1, Bulaksumur, Yogyakarta 55281, Indonesia \\ *Penulis korespondensi: Siti M.F., Email: fiqtinovri@gmail.com
}

Tanggal submisi: 9 Maret 2018; Tanggal penerimaan: 12 November 2019

\begin{abstract}
ABSTRAK
Pati biji lai (Durio kutejensis) cepat mengalami retrogradasi dan kestabilan pasta rendah sehingga dalam penggunaannya di bidang pangan kurang meluas. Hal ini dapat diatasi dengan cara modifikasi pati secara asetilasi menggunakan asetat anhidrat. Pati biji lai diasetilasi menggunakan asetat anhidrat konsetrasi $3 \%$ dan $4 \%$, variasi waktu reaksi 15, 30, 45, dan 60 menit dan pH reaksi yang digunakan berkisar pada 8-8,5. Hasil yang berupa pati asetat biji lai kemudian dibandingkan dengan pati alaminya. Asetilasi pati biji lai menghasilkan derajat subtitusi (DS) tertinggi pada konsentrasi asetat anhidrat 4\% yang direaksikan selama 15 menit, yaitu 0,22 dan memiliki tipe kristalinitas A. Hasil FTIR menunjukkan munculnya peak baru pada panjang gelombang $1735 \mathrm{~cm}^{-1}$ yang merupakan gugus karbonil dan melemahnya puncak gugus hidroksil pada pati asetat. Modifikasi pati biji lai secara asetilasi menurunkan viskositas puncak dari $1472 \mathrm{cP}$ menjadi $1170 \mathrm{cP}$, nilai setback dari $172 \mathrm{CP}$ menjadi 31cP, breakdown dari $798 \mathrm{cP}$ menjadi $350 \mathrm{cP}$ namun meningkatkan suhu gelatinisasi dari $75,85^{\circ} \mathrm{C}$ menjadi $78,20^{\circ} \mathrm{C}$. Hal ini membuktikan bahwa modifikasi pati secara asetilasi pada biji lai dapat meningkatkan ketahanan terhadap retrogradasi dan menstabilkan pasta pati. Tingginya suhu gelatinisasi pati asetat biji lai dapat dimanfaatkan pada industri pangan yang membutuhkan suhu tinggi dalam proses produksinya.
\end{abstract}

Kata kunci: Asetilasi; lai; modifikasi pati; pati biji lai

\begin{abstract}
Lai (Durio kutejensis) seed starches have a high retrogradation ability and low paste stability so that its function in food industry is less widespread. This phenomenon can be overcome by starches modification, such as acetylation using asetat anhidrat as modifying agent. Lai seed starches was acetylated using asetat anhidrat 3\% and $4 \%$, the reaction time variation was $15,30,45$ and 60 minutes and the reaction $\mathrm{pH}$ used ranged from 8-8.5. The results were compared with the navite lai seed starch.Acetylation with a different amount of asetat anhidrat ( $3 \%$ and $4 \%$ ) and different time of reaction $(15,30,45,60 \mathrm{~min}$ ) give an optimum result of DS in $4 \%$ of asetat anhidrat with 15 minute of reaction time. DS that reached at those condition is 0.22 and has the same tipe as native starch (tipe A). The result of FTIR shown that there's a new peak at $1735 \mathrm{~cm}^{-1}$ which is a part of carbonyl group and the weakening of hydroxyl group peak of acetate starch. Acetylation decreased the final viscosity from $1472 \mathrm{cP}$ to $1170 \mathrm{cP}$, setback value from $172 \mathrm{cM}$ to $31 \mathrm{cP}$, and breakdown from $798 \mathrm{cP}$ to $350 \mathrm{cP}$. Meanwhile, the
\end{abstract}


pasting temperature increased after acetylation from $71.82{ }^{\circ} \mathrm{C}$ to $76.05^{\circ} \mathrm{C}$. These result indicate that acetylation increased the resistance of retrogradation, and high pasting stability.

Keywords: Acetylation; lai; starch modification; starch of lai seed

\section{PENDAHULUAN}

Lai atau Durio kutejensis, merupakan buah asli Kalimantan Timur yang jarang dijumpai di luar pulau Kalimantan. Penampilan luar lai persis sama seperti durian, namun lai memiliki ukuran yang lebih kecil dan warna lebih kuning bila dibandingkan durian. Kemiripan durian (Durio zibethinus) dengan lai (Durio kutejensis) telah dilaporkan oleh (Santoso dan Saleh, 2013) dengan presentase kemiripan sebesar $31,8 \%$. Biji lai, yang merupakan limbah yang melimpah ketika musim panen, berpotensi sebagai salah satu sumber pati.

Pada industri pangan, pati umumnya digunakan sebagai binding dan thickening agent, oleh sebab itu karakteristik pati seperti daya kembang, kelarutan, freeze-thaw stability, kejernihan pasta, dan kekuatan gel berperan penting untuk menghasilkan produk makanan berbasis pati yang berkualitas. Sementara itu, berdasarkan Ashri dkk. (2017), pati biji lai memiliki nilai kelarutan $(9,68 \%)$, daya kembang $(10,79(\mathrm{~g} / \mathrm{g}))$, dan kestabilan pasta yang rendah serta cepat mengalami retrogradasi. Hal ini dapat diatasi dengan cara modifikasi. Modifikasi pati biji lai telah dilakukan oleh Ashri dkk. (2017) menggunakan sodium tripolipospat (STPP) dan memberikan hasil pada peningkatan viskositas pati alami biji lai yang dapat diaplikasikan sebagai bahan pengental saus dan sup krim, serta bahan pangan lain yang membutuhkan pati dengan tingkat kekentalan tinggi. Selain posporilasi, modifikasi pati biji lai juga dapat dilakukan secara asetilasi.

Modifikasi pati secara asetilasi bekerja dengan mensubtitusi gugus - $\mathrm{OH}$ (hidroksil) dengan gugus asetat dan umumnya modifying agent yang digunakan adalah asetat anhidrat. Semakin tinggi konsentrasi modifying agent dan semakin lama waktu reaksi, derajat subtitusi (DS) akan semakin tinggi (Colussi dkk., 2015 ; BelloPérez dkk., 2010), namun akan mengalami titik jenuh pada waktu reaksi atau jumlah modifying agent tertentu dan menurunkan efisiensi reaksi (Xu dkk., 2004). Tinggi rendahnya derajat subtitusi (DS) yang dihasilkan dari proses asetilasi dipengaruhi oleh beberapa faktor seperti konsentrasi reaktan, waktu reaksi, pH dan adanya katalis (Rizka dan Andri, 2016) serta berbagai faktor internal lain seperti jenis pati, struktur, dan panjang rantai amilosa/amilopektin.

Pati asetilasi dengan DS rendah $(0,01-0,2)$ dan sesuai dengan anjuran Food and Drug Assosiation
(FDA) untuk produk pangan, dapat meningkatkan sifat fungsional pati alami, seperti peningkatan pada nilai kelarutan dan swelling power (Singh dkk., Lawal, 2004; Colussi dkk., 2014; FDA, 2017), serta menghambat laju retrogradasi sehingga tingkat kejernihan pasta juga semakin tinggi (Huang dkk., 2007; Polyana \& Puturuhu, 2016; El Halal dkk., 2017). Berdasarkan penelitian pendahuluan yang telah dilakukan, DS pati asetat biji lai yang paling mendekati rekomendasi FDA adalah modifikasi pada kondisi reaksi dengan $\mathrm{pH} 8-8,5$ dengan kisaran jumlah asetat anhidrat 3-4\% (data tidak ditampilkan). Hasil ini sama dengan penelitian (Mbougueng dkk., 2012; Colussi dkk., 2015; Shah dkk., 2017), yang melakukan asetilasi pati menggunakan asetat anhidrat dengan kisaran pH $8-8,5$ dan kisaran waktu reaksi 5-60 menit.

Oleh sebab itu, dilakukan modifikasi pati biji lai dengan cara asetilasi untuk menghasilkan pati asetat DS rendah sesuai dengan anjuran maksimal FDA untuk produk pangan, dengan kisaran $\mathrm{pH} 8-8,5$, konsentrasi asetat anhidrat $3 \%$ dan $4 \%$, serta waktu reaksi (15, 30, 45, dan 60 menit). Penelitian ini juga bertujuan untuk mengamati sifat fisik pati asestat biji lai sepertiswelling power dan kelarutan, sifat morfologi, dan sifat amilografnya (laju retrogradasi, viskositas, suhu gelatinisasi). Hasil penelitian akan dibandingkan dengan pati alami biji lai, sehingga dapat menjadi dasar dalam memperluas kemungkinan penggunaan pati asetat biji lai dalam industri pangan.

\section{METODE PENELITIAN}

\section{Bahan}

Bahan utama yang digunakan pada penelitian ini adalah biji lai (Durio kutejensis), diambil dari Tanjung Selor (Kalimantan Utara) dengan tingkat kematangan buah dilihat pada warna kulitnya yang telah kuning sempurna. Bahan kimia yang digunakan antara lain asetat anhidrat, natrium hidroksida $(\mathrm{NaOH}) 2 \mathrm{M}$, asam klorida $(\mathrm{HCl}) 0,5 \mathrm{M}$, aquades, Iodin (I2), etanol, potasium hidroksida $(\mathrm{KOH})$.

\section{Alat}

Alat yang digunakan adalah $\mathrm{pH}$ meter, water bath, oven, pengering kabinet, mortar, blender, ayakan 60 mesh, kain saring, erlenmeyer, gelas ukur, magnetic 
stirrer, vacuum filter, timbangan, loyang, alumunium foil,centrifuge. Alat pengujian yang digunakan antara lain Scanning Electron Microscope (SEM JSM6510LA), RVA Tecmaster, X-Ray Defractometer, FT-IR Spectrophotometer 8201PC Shimadzu.

\section{Tahapan Penelitian}

\section{Ekstraksi pati biji la}

Ekstraksi pati dilakukan berdasarkan penelitian pendahuluan. Biji dikupas kemudian dihaluskan menggunakan blender dengan tambahan air menggunakan perbandingan $1: 2(\mathrm{~b} / \mathrm{v})$, selama 10 20 menit. Hancuran biji yang telah halus disaring menggunakan kain saring hingga mengeluarkan air yang bercampur lendir (seed gum). Ampas biji dicuci kembali dan disaring, kemudian air hasil perasan dimasukkan ke dalam falcon $50 \mathrm{~mL}$ untuk dipisahkan fraksi pati, air, dan seed gum menggunakan centrifuge. Endapan berupa pati kemudian dikeringkan menggunakan pengering kabinet pada suhu $50{ }^{\circ} \mathrm{C}$ selama 12 jam (kadar air berkisar $8-13 \%)$. Pati yang dihasilkan berupa pati kasar yang kemudian dihaluskan kembali menggunakan mortar dan diayak dengan ayakan 60 mesh.

\section{Asetilasi pati biji lai}

Asetilasi dilakukan dengan memodifikasi metode Phillips dkk. (1999) yang telah diterapkan pada beberapa studi sebelumnya. Pati biji lai $10 \mathrm{~g}$ ditambahkan $25 \mathrm{~mL}$ aquades dan diaduk menggunakan magnetik stirrer pada suhu ruang selama 30 menit. $\mathrm{pH}$ diatur menggunakan larutan $\mathrm{NaOH}$ encer $2 \mathrm{M}$ hingga meningkat menjadi pH 8. Kemudian ditambahkan asetat anhidrat sesuai perlakuan berdasarkan penelitian pendahuluan, yaitu $3 \%$ dan $4 \%(\mathrm{v} / \mathrm{w})$, dan $\mathrm{pH}$ tetap dijaga agar tidak lebih dari 8-8,5 dan terus diaduk sesuai perlakuan (15, 30, 45, dan 60 menit). Setelah itu endapan (slurry) yang terbentuk diatur $\mathrm{pH}$-nya dengan menambahkan $0.5 \mathrm{M} \mathrm{HCl}$ sampai $\mathrm{pH} 4,5-5$, kemudian disentrifugasi pada kecepatan $3600 \mathrm{rpm}$ selama 15 menit. Endapan pati dicuci dua kali menggunakan aquades untuk menghilangkan asam yang terkandung di dalam larutan. Pati asetat basah kemudian dikeringkan dengan oven pada suhu $50^{\circ} \mathrm{C}$ selama 12 jam (8-14\%) lalu dihaluskan dengan mortar dan diayak pada ukuran 60 mesh sehingga menghasilkan pati asetat kering.

\section{Analisis pati biji lai}

Analisis derajat subtitusi (DS) dengan cara titrasi (metode Wurzburg, 1978), swelling power (Wongsagonsup dkk., 2014), dan kelarutan pati (Lawal dkk, 2004). Uji lanjut dilakukan pada pati asetat dengan tingkat kelarutan dan swelling power maksimal namun tetap dalam kisaran DS yang diizinkan FDA untuk industri pangan $(0,01-0,2)$. Uji lanjut meliputi:

1. Kadar amilosa (Yu dkk., 2012)

2. Morfologi granula pati menggunakan SEM (Miao dkk., 2018)

3. Kristanilitas pati menggunakan XRD (Matveev dkk., 2001)

4. Kemunculan gugus asetat menggunakan Fourier Transform Infared (FTIR) Spectroscopy (Kim dkk., 2008)

5. Sifat amilograf (laju retrogradasi, viskositas, dan suhu gelatinisasi) menggunakan RVA Tecmaster (Kittipongpatana dkk., 2006).

\section{Analisis Data}

Data hasil pengamatan sifat kimia dianalisis dengan analisis ragam (uji F). Jika berpengaruh nyata, maka dilanjutkan dengan uji lanjut Duncan Multiple Range Test (DMRT) dengan tingkat kepercayaan 5\%.

\section{HASIL DAN PEMBAHASAN}

Rendemen pati asetat berkisar antara $73-85 \%$ dari pati alami biji lai untuk kedua jumlah asetat anhidrat yang berbeda (3 dan 4\%). Sementara untuk efek konsentrasi asetat anhidrat dan waktu reaksi terhadap DS dijabarkan pada Tabel 1. Berdasarkan Tabel 1, terdapat perbedaan DS antara konsetrasi 3\% dan 4\%, meskipun waktu reaksi yang diterapkan sama. Hal ini menunjukkan bahwa konsentrasi modifying agent (asetat anhidrat) dan lamanya waktu reaksi sangat berpengaruh terhadap naik turunnya DS.

Tabel 1. Derajat subtitusi pati biji lai asetat

\begin{tabular}{ccc}
\hline $\begin{array}{c}\text { Asetat anhidrat } \\
(\mathrm{v} / \mathrm{w})\end{array}$ & $\begin{array}{c}\text { Waktu reaksi } \\
\text { (menit) }\end{array}$ & DS \\
\hline & 15 & $0,11^{\mathrm{d}}$ \\
$3 \%$ & 30 & $0,10^{\mathrm{de}}$ \\
& 45 & $0,14^{\mathrm{c}}$ \\
& 60 & $0,15^{\mathrm{c}}$ \\
$4 \%$ & 15 & $0,22^{\mathrm{a}}$ \\
& 30 & $0,17^{\mathrm{b}}$ \\
& 45 & $0,15^{\mathrm{c}}$ \\
& 60 & $0,09^{\mathrm{e}}$ \\
\hline
\end{tabular}

Huruf yang sama pada kolom yang sama menandakan tidak berbeda nyata pada taraf ketelitian $5 \%$ 
DS pada konsentrasi asetat anhidrat 3\% (v/w) semakin tinggi seiring dengan meningkatnya waktu reaksi. Seperti yang diketahui, DS pati asetilasi akan semakin tinggi seiring meningkatnya konsentrasi asetat anhidrat yang digunakan (Han dkk., 2013; Colussi dkk., 2015), karena semakin lama waktu reaksi, semakin banyak pula gugus $-\mathrm{OH}$ yang tersubtitusi oleh gugus asetil. Pada waktu reaksi 15 menit dengan konsentrasi asetat anhidrat $3 \%(\mathrm{v} / \mathrm{w})$, DS yang tercapai adalah sebesar 0,11. Hasil ini tidak berbeda nyata bila dibandingkan dengan asetilasi selama 30 menit. DS mengalami peningkatan dan mencapai puncak pada waktu reaksi 60 menit. Penelitian yang dilakukan oleh Ayucitra, (2012) untuk pati kentang dan Halal dkk. (2015) untuk pati barley, menggunakan waktu reaksi 60 menit sebagai waktu reaksi ideal. Hal ini dimungkinkan pada waktu tersebut, interaksi antara pati dengan gugus asetat sudah berlangsung optimal. Hasil ini sejalan pula dengan Mbougueng dkk. (2012), bahwa pati kentang Siplera yang direaksikan dengan asetat anhidrat selama 20 menit memiliki DS lebih tinggi dibandingkan dengan reaksi selama 10 menit. Berbeda dengan konsentrasi asetat anhidrat $3 \%(\mathrm{v} / \mathrm{w})$, pada konsentrasi asetat anhidrat $4 \%(\mathrm{v} / \mathrm{w})$ waktu reaksi yang semakin lama menurunkan DS, dengan DS tertinggi di waktu reaksi 15 menit (Tabel 1). Terjadinya penurunan DS ini dapat dimungkinkan dengan konsentrasi asetat anhidrat 4\% (v/w) pada waktu reaksi 15 menit, subtitusi antara gugus $(-\mathrm{OH})$ pati biji lai dengan gugus asetil sudah berjalan optimal, sehingga semakin lama waktu reaksi maka efisiensi subtitusinya semakin menurun. Hasil ini sama dengan penelitian sebelumnya oleh Singh dkk., (2004); Han dkk., (2013); Colussi dkk., (2015), yang menunjukkan adanya kecenderungan bahwa semakin tinggi konsentrasi asetat anhidrat, maka DS akan semakin tinggi pula, namun hal tersebut hanya sampai batas tertentu yaitu pada saat gugus hidroksil sudah jenuh tersubtitusi.

Damat dkk. (2008) menyatakan bahwa kecepatan reaksi akan meningkat seiring dengan meningkatnya konsentrasi reaktan. Hal ini membuktikan bahwa semakin tinggi konsentrasi asetat anhidrat dan semakin lama waktu reaksi, maka efisiensi reaksi akan menurun karena terjadinya proses hidrolisis pati. Menurunnya efisiensi reaksi yang terjadi akibat banyaknya kosentrasi asetat anhidrat yang ditambahkan dan lamanya waktu reaksi, dapat dijelaskan pula melalui mekanisme adisieliminasi. Proses adisi-eliminasi terjadi bila dalam kondisi tertentu gugus asetil yang sudah teresterifikasi, dapat tereliminasi dari pati asetat (Xu dkk., 2004). Mekanisme ini terjadi selama proses esterifikasi yang terjadi pada atom C6, C2, dan C3. Salah satu dari ketiga gugus $(-\mathrm{OH})$ bebas pada pati menunjukkan reaktifitas yang berbeda (Xu dkk., 2004; Garg dan Jana, 2011; Colussi dkk., 2016; Xu dan Shi, 2019). Atom C6 pada gugus (-OH) lebih reaktif dan mudah tersubtitusi dibandingkan atom C2 dan C3, sementara C2 lebih reaktif dibandingkan C3. Proses adisi-eliminasi terjadi bila dalam kondisi tertentu gugus asetil yang sudah teresterifikasi, dapat tereliminasi dari pati asetat (Xu dkk., 2004). Selain itu juga dimungkinkan bahwa pati asetat dapat mengalami hidrolisis yang kemudian menyebabkan terjadinya eliminasi gugus asetat dari pati asetatnya.

\section{Solubility dan Swelling Power}

Nilai kelarutan (solubility) pada pati asetat biji lai lebih tinggi dibandingkan dengan pati alami biji lai, sejalan dengan penelitian Singh dkk. (2004), bahwa kelarutan pati asetat lebih tinggi dibandingkan dengan pati alaminya.

Sementara itu, pengembangan (swelling) granula pati terjadi karena adanya tambahan air yang kemudian dipanaskan pada suhu tinggi. Swelling power pati asetat biji lai lebih tinggi dibandingkan dengan pati alami biji lai. Hal ini sama dengan hasil penelitian Bartz dkk. (2015) dan Susetyo dkk. (2016), bahwa swelling power pada pati asetat lebih tinggi dibandingkan pati alami biji lai, namun tidak berbeda nyata antara pati asetat satu dan lainnya.

\section{Uji Lanjut Pati Asetat Biji lai}

Berdasarkan Tabel 2, pati asetat biji lai yang memiliki nilai swelling power dan kelarutan paling tinggi serta masih masuk dalam kisaran DS yang diizinkan

Tabel 2. Swelling power dan solubility

\begin{tabular}{cccc}
\hline \multirow{2}{*}{$\begin{array}{c}\text { Asetat anhidrat } \\
(\mathrm{v} / \mathrm{w})\end{array}$} & DS & \multicolumn{2}{c}{ Pati lai } \\
\cline { 3 - 4 } & & $\begin{array}{c}\text { Swelling } \\
\text { power }(\mathrm{g} / \mathrm{g})\end{array}$ & $\begin{array}{c}\text { Solubility } \\
(\%)\end{array}$ \\
\hline \multirow{3}{*}{$3 \%$} & Alami* $^{\circ}$ & $10,79^{\mathrm{e}}$ & $9,68^{\mathrm{f}}$ \\
& 0,11 & $11,14^{\mathrm{d}}$ & $13,39^{\mathrm{e}}$ \\
& 0,10 & $11,16^{\mathrm{d}}$ & $13,39^{\mathrm{e}}$ \\
& 0,14 & $11,18^{\mathrm{d}}$ & $15,35^{\mathrm{c}}$ \\
& 0,15 & $11,20^{\mathrm{d}}$ & $15,40^{\mathrm{b}}$ \\
& 0,22 & $11,63^{\mathrm{a}}$ & $16,32^{\mathrm{a}}$ \\
& 0,17 & $11,43^{\mathrm{b}}$ & $15,39^{\mathrm{c}}$ \\
& 0,15 & $11,33^{\mathrm{c}}$ & $14,62^{\mathrm{d}}$ \\
& 0,09 & $11,32^{\mathrm{c}}$ & $14,32^{\mathrm{d}}$ \\
\hline
\end{tabular}

*Ashri dkk. (2017)

Huruf yang sama pada kolom yang sama menandakan tidak berbeda nyata pada taraf ketelitian $5 \%$ 
oleh FDA untuk produk pangan adalah 0,22 (konsentrasi asetat anhidrat 4\%, waktu reaksi 15 menit). Oleh sebab itu, pati asetat biji lai inilah yang dipilih untuk diuji lanjut.

\section{Kadar amilosa}

Kadar amilosa pati asetat biji lai dengan DS 0,2 lebih tinggi namun tidak berbeda nyata dengan pati alaminya, dimana kadar amilosa pati alami biji lai 25,07\% (Ashri dkk., 2017) dan pati asetat 26,16\%. Sama halnya dengan hasil dari penelitian Mbougueng dkk. (2012) yang memodifikasi pati kentang dan singkong, kadar amilosa keduanya meningkat setelah asetilasi meskipun tidak berbeda nyata. Hal ini menunjukkan bahwa proses asetilasi, dimana gugus asetat yang ditambahkan pada kondisi alkali, menyerang daerah amorf amilopektin pada ikatan a 1-6 glikosida yang kemudian menggantikan gugus hidroksil $(-\mathrm{OH})$ dengan gugus asetat. Hal ini sesuai dengan yang diungkapkan oleh Huang dkk., (2007) bahwa fase amorf jauh lebih mudah diakses selama reaksi dibandingkan fase kristalin. Kondisi ini kemudian menyebabkan terjadinya perbedaan berat molekul pada pati.

\section{$X$-ray diffraction pati asetat biji lai}

Berdasarkan hasil penelitian Ashri dkk. (2017), biji lai memiliki tipe kristalin $A$ dengan pola seperti yang terlihat pada Gambar 1 a. Puncak pada $2 \theta$ yaitu 17,16 ; 15,$38 ; 18,30$. Struktur pati tipe A biasanya terdapat pada serealia, memiliki panjang rantai amilopektin sebanyak 23 - 29 unit glukosa. Perubahan tipe pati merupakan gambaran adanya perubahan struktur kristalinitas pada struktur pati, yang umumnya diakibatkan oleh subtitusi antara gugus asetat anhidrat dengan gugus (-OH) (Zhang dkk., 2009). Namun, asetilasi tidak mempengaruhi secara nyata terhadap perubahan tipe pati biji lai. Hal ini dapat dikarenakan gugus asetat hanya menyerang bagian amorf dari pati biji lai, sama dengan yang telah dilaporkan oleh Lawal (2004) pada pati Xanthosoma sagittifolium.

Pada hasil X-Ray, tidak terjadi perubahan tipe pati setelah pati biji lai dimodifikasi. Puncak muncul pada $2 \theta$ adalah 16,$54 ; 14,74 ; 17,52$ yang masih merupakan kisaran puncak pati dengan tipe kristalinitas A (Gambar 1b). Hal ini sama dengan hasil yang diperoleh oleh Chen dkk. (2004); Huang dkk. (2007); Bartz dkk. (2015); dan Shah dkk. (2017), bahwa tidak ada perubahan pada puncak kristalinitas setelah pati dimodifikasi, namun terjadi penurunan tingkat kristalinitas pada pati dengan DS rendah, hal ini dilihat dari berkurangnya intensitas pada puncak yang sama. Ketika sebagian gugus hidroksil disubtitusi oleh gugus asetil, gugus hidroksil yang masih tersisa akan menyesuaikan diri untuk kembali membentuk ikatan hidrogen yang kemudian menyebabkan tetapnya puncak kristalinitas tetapi intensitasnya menjadi sedikit berkurang (Lawal, 2004).

\section{Gugus Fungsi Pati Alami Biji Lai dan Pati Asetat Biji Lai}

Spektrum FTIR pati alami biji lai (Gambar 2a) menunjukkan kemunculan gugus $\mathrm{O}-\mathrm{H}$ pada puncak $3387 \mathrm{~cm}^{-1}$ yang merupakan ikatan hidrogen pada molekul pati. Ada beberapa karakteristik tambahan yang terabsorbsi pada puncak 925,83; 856,39; 756,10; $578,64 \mathrm{~cm}^{-1}$ yang terjadi karena adanya perenggangan rantai anhidroglukosa (Han dkk., 2013). Ikatan C-H ditemukan pada puncak 1491,61 dan 1365,60 cm (Skoog dkk., 1998).

Besarnya intensitas, luas area dan tinggi dari puncak FTIR tergantung pada DS, dimana dengan meningkatnya DS, intensitas puncak, area dan tinggi juga akan meningkat dan semakin lama semakin menghilang (Han dkk., 2013). Pati biji lai hasil asetilasi memiliki 19 puncak sementara pati alami 15 puncak. Pada Gambar $2 \mathrm{~b}$, puncak pada panjang gelombang $3387 \mathrm{~cm}-1$

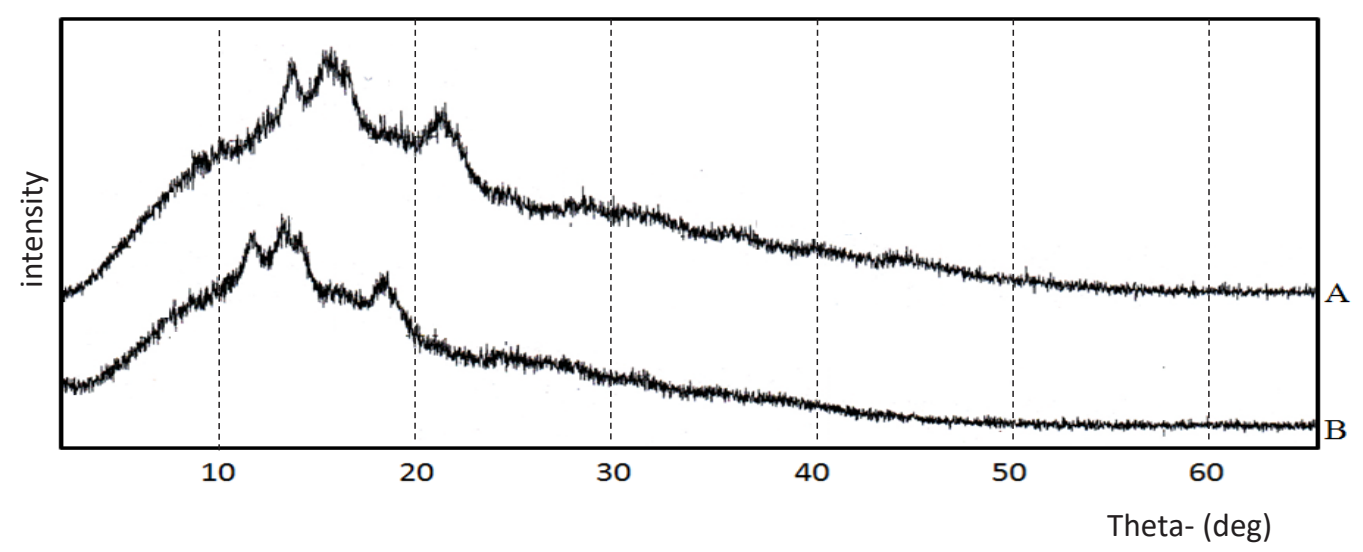

Gambar 1. XRD (a) pati alami dan (b) pati asetat biji lai 


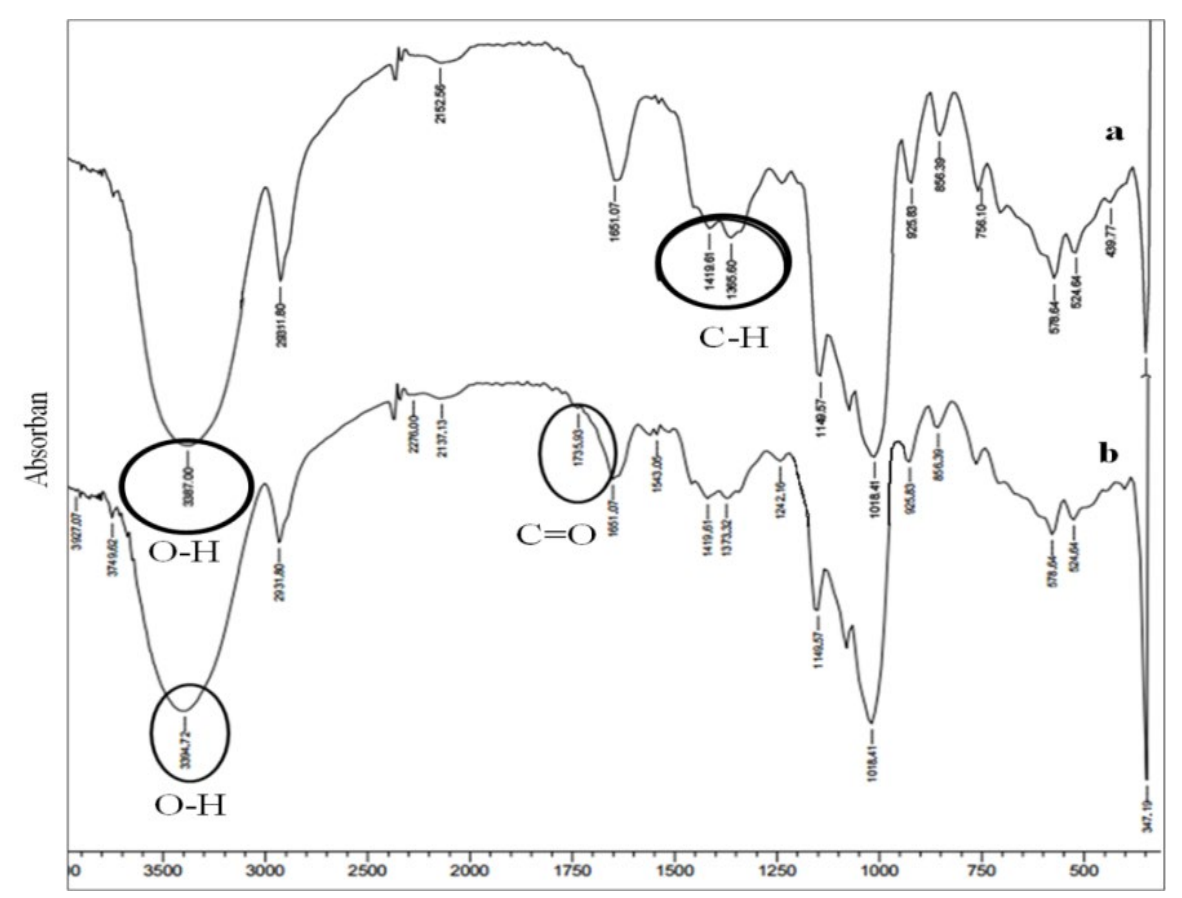

Gambar 2. Hasil uji FTIR (a) pati alami biji lai (b) pati asetat biji lai

melemah pada pati asetat yang berhubungan dengan gugus $\mathrm{O}-\mathrm{H}$. Semakin meningkatnya DS, puncak gugus $\mathrm{O}-\mathrm{H}$ akan semakin melemah dan dapat menghilang (Chi dkk., 2008; Bello-Pérez dkk., 2010; Diop dkk., 2011; Han dkk., 2013).

Munculnya puncak baru pada panjang gelombang $1735,93 \mathrm{~cm}^{-1}$ pada pati asetat biji lai menandakan kemunculan gugus $\mathrm{C}=\mathrm{O}$ yang merupakan gugus metil dari grup asetat dan menurut (Han dkk., 2013) akan semakin meningkat dengan meningkatnya DS. Sedangkan pada bilangan gelombang 1651,07 terjadi pengurangan yang menandakan adanya perenggangan $\mathrm{C}-\mathrm{O}-\mathrm{C}$ yang dapat dikaitkan dengan keberadaan air pada molekul pati dan merupakan hasil dari afinitas yang rendah terhadap air bila dibandingkan dengan pati alami (Colussi dkk., 2014).

\section{Sifat Amilografi Pati Asetat Biji Lai}

Viskositas puncak pati asetat biji lai lebih rendah bila dibandingkan dengan pati alami biji lai (Tabel 2). Pada pati alami biji lai, viskositas puncak berada pada $2143 \mathrm{CP}$ sementara pati asetat biji lai lebih rendah yaitu 1489 CP. Menurunnya viskositas puncak pati asetat dikarenakan adanya gugus asetat yang menggantikan gugus hidroksil sehingga membatasi pembentukan kekuatan dalam mengikat air (Lawal, 2004). Menurut Damat dkk., (2008) yang telah melakukan esterifikasi pati garut menggunakan butirat anhidrat, semakin besar DS maka semakin rendah pula viskositas puncaknya, dan didukung pula oleh Bello-Pérez dkk., (2010) yang memodifikasi pati barley secara esterifikasi (menggunakan asetat anhidrat).

Nilai breakdown menunjukkan nilai penurunan viskositas selama pemanasan yang berhubungan terhadap kestabilan pasta selama proses pemanasan. Pati asetat biji lai memiliki nilai breakdown lebih rendah dari pati alami biji lai. Hasil ini sama dengan yang dilaporkan Colussi dkk., (2014), bahwa proses asetilasi menurunkan breakdown pati beras. Menurunnya nilai breakdown menunjukkan stabilitas pasta yang lebih tinggi (semakin stabil) terhadap panas (ketahanan terhadap gaya geser menipis selama pati dimasak). Hal ini membuktikan bahwa perlakuan asetilasi dapat meningkatkan kestabilan pasta pati biji lai, yang merupakan batasan dari pati alaminya (kestabilan pasta rendah).

Setback menunjukkan nilai dari ketahanan terhadap retrogradasi atau sineresis pada pati (Adebowale dkk., 2005). Setback pati alami biji lai lebih tinggi dibandingkan pati asetat biji lai. Hal ini dapat dikarenakan adanya introduksi gugus asetat pada pati biji lai menyebabkan terhambatnya retrogradasi. Pada suhu dingin setelah dipanaskan, gugus asetat mampu menghambat kecenderungan molekul-molekul pati untuk bergabung kembali, dan hal inilah yang mempengaruhi nilai setback. Hasil ini sama seperti yang telah dilaporkan oleh Saartrat dkk., 2005 ; Adebowale dkk., 2005 dan Simsek dkk., 2012. Hasil ini 
Tabel 3. Sifat amilograf pati alami biji lai dan pati asetat biji lai

\begin{tabular}{ccccccc}
\hline \multirow{2}{*}{ Sampel } & \multicolumn{5}{c}{ Viskositas (cP) } & \multirow{2}{*}{ Suhu gelatinisasi } \\
\cline { 2 - 6 } & PV & TV & BV & FV & SV & \\
\hline Pati Alami Biji Lai* & 1472 & 1345 & 127 & 2143 & 798 & $75.85^{\circ} \mathrm{C}$ \\
Pati Asetat Biji Lai & 1170 & 1139 & 31 & 1489 & 350 & $78.20^{\circ} \mathrm{C}$ \\
\hline
\end{tabular}

Keterangan: $\mathrm{PV}=$ peak viscosity; $\mathrm{TV}=$ trough viscosity; $\mathrm{BV}=$ breakdown viscosity; $\mathrm{FV}=$ final viscosity; $\mathrm{SV}=$ setback viscosity.

*Ashri dkk., (2017)

membuktikan bahwa proses asetilasi dapat menurunkan nilai retrogradasi, yang merupakan batasan dari pati biji lai yang cepat mengalami retrogradasi.

Suhu gelatinisasi (pasting temperature) mengalami peningkatan setelah pati biji lai diasetilasi. Hal ini dimungkinkan karena sifat hidrofobik pada pati asetat yang kemudian menghambat proses gelatinisasi dan hasil ini sejalan dengan Cahyana dkk., (2011) yang melakukan asetilasi pati beras. Gugus asetil lebih bersifat non polar bila dibandingkan gugus $-\mathrm{OH}$, sehingga untuk mencapai suhu gelatinisasinya membutuhkan energi yang lebih tinggi. Hasil ini bertolak belakang dengan Sodhi dan Singh, (2005) dan Colussi dkk., (2015), yang mengalami penurunan suhu gelatinisasi pada asetilasi pati beras. Sodhi dan Singh, (2005) menyatakan, penurunan suhu gelatinisasi dikarenakan terjadinya pembukaan awal dari amilopektin heliks ganda dan gabungan dari lemela kristal pati, yang disebabkan oleh proses asetilasi. Perbedaan ini dapat dijelaskan bahwa sumber pati yang berbeda memiliki pengaruh yang berbeda pula terhadap suhu gelatinisasi setelah dimodifikasi, tergantung dari jenis, bentuk granula dan panjang rantai pati tersebut. Selain itu, suhu gelatinisasi juga dipengaruhi oleh konsentrasi pati, serta adanya komponen lain seperti gula, asam dan $\mathrm{pH}$.

Tingginya tingkat ketahannya terhadap retrogradasi, kestabilan pasta yang lebih stabil, dan tingginya suhu gelatinisasi pada pati asetat biji lai dapat menjadi pertimbangan untuk penggunaanya pada produk pangan yang proses produksinya membutuhkan suhu tinggi.

\section{Granula Pati}

Bentuk granula pati biji lai ditunjukkan pada Gambar 3 dimana tidak tampak perbedaan signifikan antara pati alami biji lai (Gambar 3a dan 3b) dengan pati asetat biji lai (Gambar 3e dan 3f). Pati alami biji lai memiliki bentuk morfologi yang tidak beraturan dan memiliki ukuran partikel 0,456 $\mu \mathrm{m}$ hingga 4,853 $\mu \mathrm{m}$. Pati asetat biji lai (Gambar 3h) memiliki granula yang sedikit lebih kompak dibandingkan pati alami biji lai (Gambar 3d). Hal ini sama seperti yang diungkapkan oleh Singh dkk., (2004) dan Sodhi dan Singh, (2005).
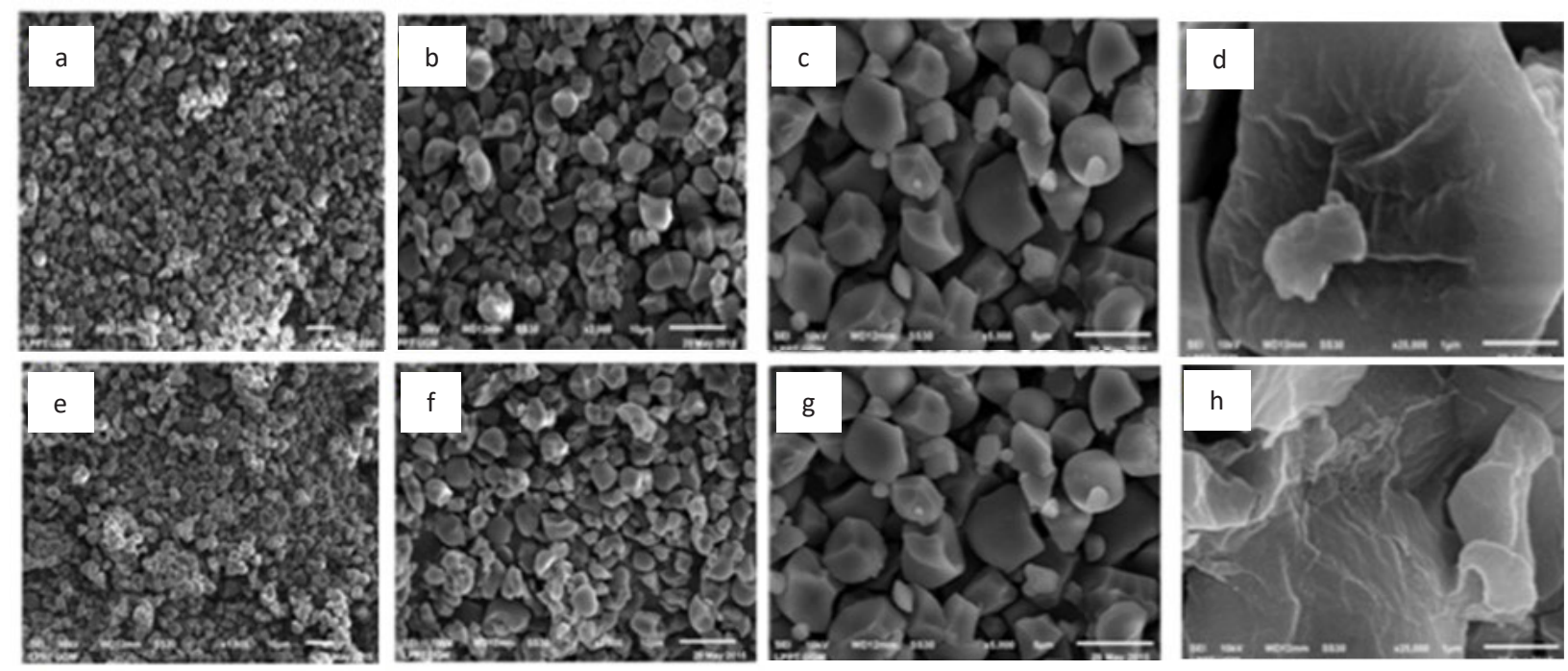

Gambar 3. SEM (a) (b) (c) (d) pati alami biji lai, (e) (f) (g) (h) pati asetat biji lai ; perbesaran (a) dan (e) 1000x, (b) dan (f) 2000x, (c) dan (g) 5000x, (d) dan (h) 25000x 


\section{KESIMPULAN}

Modifikasi secara asetilasi pada pati biji lai meningkatkan nilai swelling power dan kelarutan bila dibandingkan dengan pati alaminya dan meningkatkan ketahanannya terhadap retrogradasi serta meningkatkan stabilitas pastanya terhadap panas. Selain itu, asetilasi juga meningkatkan suhu gelatinisasi pati biji lai, sehingga pati asetat ini dapat diaplikasikan sebagai bahan pangan fungsional yang membutuhkan suhu tinggi pada proses produksinya seperti bahan dalam pembuatan nugget atau frozen food lainnya. Namun hal ini masih harus dilakukan penelitian dan uji lebih lanjut.

\section{UCAPAN TERIMA KASIH}

Terima kasih kepada Bapak Tjatjuk dan Ibu Teti Kudsiati atas bahan utama penelitian (biji lai). Terima kasih pula kepada pihak Dikti yang telah memberikan bantuan dana sehingga penelitian ini dapat terlaksana dan berjalan lancar.

\section{KONFLIK KEPENTINGAN}

Tidak ada konflik kepentingan dalam penelitian ini.

\section{DAFTAR PUSTAKA}

Adebowale, K. O., Olu-Owolabi, B. I., Olawumi, E. K., \& Lawal, O. S. (2005). Functional properties of native, physically and chemically modified breadfruit (Artocarpus artilis) starch. Industrial Crops and Products, 21(3), 343-351. https://doi.org/10.1016/j. indcrop.2004.05.002

Ashri M. Benita, Siti M. Fiqtinovri, Djagal W. Marseno, Yudi P. (2017). PENGARUH FOSFORILASI TERHADAP SIFAT FISIK, KIMIA, DAN PEMASTAAN PATI BIJI LAI ( Durio kutejensis ). In Agnes Murdiati dkk. (Ed.), Prosiding Seminar Nasional Pangan dan Hasil Pertanian 2016: Pengembangan Pangan Lokal untuk Meningkatkan Daya Saing Global. Yogyakarta: Gdjah Mada University.

Ayucitra, A. (2012). Preparation and Characterisation of Acetylated Corn Starches. International Journal of Chemical Engineering and Applications, 3(3), 156-159. https://doi.org/10.7763/IJCEA.2012.V3.178

Bartz, J., Goebel, J. T., Giovanaz, M. A., Zavareze, E. D. R., Schirmer, M. A., \& Dias, A. R. G. (2015). Acetylation of barnyardgrass starch with acetic anhydride under iodine catalysis. Food Chemistry, 178, 236-242. https://doi. org/10.1016/j.foodchem.2015.01.095

Bello-Pérez, L. A., Agama-Acevedo, E., Zamudio-Flores, P. B., Mendez-Montealvo, G., \& Rodriguez-Ambriz, S. L.
(2010). Effect of low and high acetylation degree in the morphological, physicochemical and structural characteristics of barley starch. LWT - Food Science and Technology, 43(9), 1434-1440. https://doi. org/10.1016/j.Iwt.2010.04.003

Cahyana, P. T., Setyowati, K., Sunarti, T. C., Haryanto, B., Agroindustri, P. T., \& Barat, J. (2011). Pembuatan pati beras termodifikasi dan pengaruh kadar amilosa terhadap sifat fungsionalnya 1, 13(3), 192-197.

Chen, Z., Schols, H. A., \& Voragen, A. G. J. (2004). Differently sized granules from acetylated potato and sweet potato starches differ in the acetyl substitution pattern of their amylose populations. Carbohydrate Polymers, 56(2), 219-226. https://doi.org/10.1016/j. carbpol.2004.02.004

Chi, H., Xu, K., Wu, X., Chen, Q., Xue, D., Song, C., ... Wang, P. (2008). Effect of acetylation on the properties of corn starch. Food Chemistry, 106(3), 923-928. https://doi. org/10.1016/j.foodchem.2007.07.002

Colussi, R., El Halal, S. L. M., Pinto, V. Z., Bartz, J., Gutkoski, L. C., Zavareze, E. da R., \& Dias, A. R. G. (2015). Acetylation of rice starch in an aqueous medium for use in food. LWT - Food Science and Technology, 62(2), 1076-1082. https://doi.org/10.1016/j.Iwt.2015.01.053

Colussi, R., Pinto, V. Z., El Halal, S. L. M., Vanier, N. L., Villanova, F. A., Marques E Silva, R., ... Dias, A. R. G. (2014). Structural, morphological, and physicochemical properties of acetylated high-, medium-, and low-amylose rice starches. Carbohydrate Polymers, 103(1), 405-413. https://doi.org/10.1016/j.carbpol.2013.12.070

Colussi, R., Zanella, V., Lisie, S., El, M., Biduski, B., Prietto, L., ... Dias, G. (2016). Acetylated rice starches films with different levels of amylose: Mechanical, water vapor barrier, thermal, and biodegradability properties. Food Chemistry. https://doi.org/10.1016/j. foodchem.2016.10.129

Damat, Haryadi, Marsono Y, Nur Cahyanto. (2008). EFEK pH DAN KONSENTRASI BUTIRAT ANHIDRIDA. Agritech, 28(2), 63-69.

Diop, C. I. K., Li, H. L., Xie, B. J., \& Shi, J. (2011). Effects of acetic acid/acetic anhydride ratios on the properties of corn starch acetates. Food Chemistry, 126(4), 16621669. https://doi.org/10.1016/j.foodchem.2010.12.050

El Halal, S. L. M., Colussi, R., Biduski, B., Evangelho, J. A. do, Bruni, G. P., Antunes, M. D., ... Zavareze, E. da R. (2017). Morphological, mechanical, barrier and properties of films based on acetylated starch and cellulose from barley. Journal of the Science of Food and Agriculture, 97(2), 411-419. https://doi.org/10.1002/jsfa.7773

Garg, S., \& Jana, A. K. (2011). Characterization and evaluation of acylated starch with different acyl groups and degrees of substitution. Carbohydrate Polymers, 83(4), 16231630. https://doi.org/10.1016/j.carbpol.2010.10.015 
Halal, S. L. M. El, Colussi, R., Pinto, V. Z., Bartz, J., Radunz, M., Carreño, N. L. V., ... Zavareze, E. D. R. (2015). Structure, morphology and functionality of acetylated and oxidised barley starches. Food Chemistry, 168, 247-256. https:// doi.org/10.1016/j.foodchem.2014.07.046

Han, F., Gao, C., Liu, M., Huang, F., \& Zhang, B. (2013). Synthesis, optimization and characterization of acetylated corn starch with the high degree of substitution. International Journal of Biological Macromolecules, 59, 372-376. https://doi.org/10.1016/j.ijbiomac.2013.04.080

Huang, J., Schols, H. A., Jin, Z., Sulmann, E., \& Voragen, A. G. J. (2007). Pasting properties and (chemical) fine structure of acetylated yellow pea starch is affected by acetylation reagent type and granule size. Carbohydrate Polymers, 68(3), 397-406. https://doi.org/10.1016/j. carbpol.2006.12.019

Kim, M. J., Choi, S. J., Shin, S. I., Sohn, M. R., Lee, C. J., Kim, Y., ... Moon, T. W. (2008). Resistant glutarate starch from adlay: Preparation and properties. Carbohydrate Polymers, 74(4), 787-796. https://doi.org/10.1016/j. carbpol.2008.04.043

Kittipongpatana, O. S., Chaichanasak, N., Kanchongkittipoan, S., Panturat, A., Taekanmark, T., \& Kittipongpatana, N. (2006). An aqueous film-coating formulation based on sodium carboxymethyl mungbean starch. Starch/ Staerke, 58(11), 587-589. https://doi.org/10.1002/ star.200600528

Lawal, O. S. (2004). Composition, physicochemical properties and retrogradation characteristics of native, oxidised, acetylated and acid-thinned new cocoyam (Xanthosoma sagittifolium) starch. Food Chemistry, 87(2), 205-218. https://doi.org/10.1016/j.foodchem.2003.11.013

Matveev, Y. I., van Soest, J. J. G., Nieman, C., Wasserman, L. A., Protserov, V. A., Ezernitskaja, M., \& Yuryev, V. P. (2001). The relationship between thermodynamic and structural properties of low and high amylose maize starches. Carbohydrate Polymers, 44(2), 151-160. https://doi. org/http://dx.doi.org/10.1016/S0144-8617(00)00211-3

Mbougueng, P. D., Tenin, D., Scher, J., \& Tchiégang, C. (2012). Influence of acetylation on physicochemical, functional and thermal properties of potato and cassava starches. Journal of Food Engineering, 108(2), 320-326. https:// doi.org/10.1016/j.jfoodeng.2011.08.006

Miao, L., Zhao, S., Zhang, B., Tan, M., Niu, M., Jia, C., \& Huang, Q. (2018). Understanding the supramolecular structures and pasting features of adlay seed starches. Food Hydrocolloids. https://doi.org/10.1016/j. foodhyd.2018.05.034

Phillips, D. L., Liu, H., Pan, D., \& Corke, H. (1999). General application of Raman spectroscopy for the determination of level of acetylation in modified starches. Cereal Chemistry, 76(3), 439-443. https://doi.org/10.1094/ CCHEM.1999.76.3.439
Polyana, F. J., \& Puturuhu, B. R. I. (2016). Preparasi dan Karakterisasi Pati Sagu Asetil. Buletin Penelitian BIAM, VI(56), 10-13.

Rizka Amalia, Andri C. Kumoro. (2016). Analisis sifat fisikokimia dan uji korelasi regresi antara nilai derajat substitusi dengan swelling power dan solubility pada tepung gadung (. Inovasi Teknik Kimia, 1(1), 17-26.

Saartrat, S., Puttanlek, C., Rungsardthong, V., \& Uttapap, D. (2005). Paste and gel properties of lowsubstituted acetylated canna starches. Carbohydrate Polymers, 61(2), 211-221. https://doi.org/10.1016/j. carbpol.2005.05.024

Santoso, P., \& Saleh, G. (2013). Phylogenetic relationships amongst 10 Durio species based on PCR-RFLP analysis of two chloroplast genes. Indonesian Journal of Agriculture, 6(1), 20-27. Retrieved from http://203.176.181.72/ index.php/ijas/article/view/639

Shah, A., Masoodi, F. A., Gani, A., \& Ashwar, B. A. (2017). LWT - Food Science and Technology Physicochemical, rheological and structural characterization of acetylated oat starches. LWT - Food Science and Technology, 80, 19-26. https://doi.org/10.1016/j.lwt.2017.01.072

Simsek, S., Ovando-Martínez, M., Whitney, K., \& BelloPérez, L. A. (2012). Effect of acetylation, oxidation and annealing on physicochemical properties of bean starch. Food Chemistry, 134(4), 1796-1803. https://doi. org/10.1016/j.foodchem.2012.03.078

Singh, N., Chawla, D., \& Singh, J. (2004). Influence of acetic anhydride on physicochemical, morphological and thermal properties of corn and potato starch. Food Chemistry, 86(4), 601-608. https://doi.org/10.1016/j. foodchem.2003.10.008

Skoog, D. a, Holler, F. J., \& Nieman, T. a. (1998). Principles of Instrumental Analysis, Brooks/Cole. The sections on atomic and molecular spectroscopy serve as excellent introductions to the subject. https://doi.org/10.1090/ S0002-9904-1936-06390-1

Sodhi, N. S., \& Singh, N. (2005). Characteristics of acetylated starches prepared using starches separated from different rice cultivars. Journal of Food Engineering, 70(1), 117127. https://doi.org/10.1016/j.jfoodeng.2004.09.018

Susetyo, Y. A., Hartini, S., \& Cahyanti, M. N. (2016). Optimasi Kandungan Gizi Tepung Ubi jalar ( Ipomoea batatas L .) Terfermentasi Ditinjau dari Dosis Penambahan Inokulum Angkak Serta Aplikasinya dalam Pembuatan Mie Basah. Jurnal Aplikasi Teknologi Pangan, 5(2), 44-51.

Wongsagonsup, R., Pujchakarn, T., Jitrakbumrung, S., Chaiwat, W., Fuongfuchat, A., Varavinit, S., ... Suphantharika, M. (2014). Effect of cross-linking on physicochemical properties of tapioca starch and its application in soup product. Carbohydrate Polymers, 101(1), 656-665. https://doi.org/10.1016/j.carbpol.2013.09.100 
Xu, J., \& Shi, Y. (2019). Position of acetyl groups on anhydroglucose unit in acetylated starches with intermediate degrees of substitution. Carbohydrate Polymers, 220(May), 118-125. https://doi. org/10.1016/j.carbpol.2019.05.059

Xu, Y., Miladinov, V., \& Hanna, M. A. (2004). Synthesis and characterization of starch acetates with high substitution. Cereal Chemistry, 81(6), 735-740. https:// doi.org/10.1094/CCHEM.2004.81.6.735
Yu, S., Ma, Y., Menager, L., \& Sun, D. W. (2012). Physicochemical Properties of Starch and Flour from Different Rice Cultivars. Food and Bioprocess Technology, 5(2), 626637. https://doi.org/10.1007/s11947-010-0330-8

Zhang, L., Xie, W., Zhao, X., Liu, Y., \& Gao, W. (2009). Study on the morphology, crystalline structure and thermal properties of yellow ginger starch acetates with different degrees of substitution. Thermochimica Acta, 495(1-2), 57-62. https://doi.org/10.1016/j.tca.2009.05.019 